\title{
Ultrastructure of ostracods as a stratigraphical tool for the subdivision of the Senonian sequence in Israel
}

\author{
AVRAHAM HONIGSTEIN \\ Geological Survey of Israel, 30 Malkhei Yisrael St., Jerusalem 95501, Israel \\ (Present affiliation: Department of Geophysics and Planetary Sciences, Tel-Aviv University, Ramat Aviv 69978, Israel)
}

\begin{abstract}
Ultrastructural size variations in pitted and ornamented Senonian ostracods from Israel are valuable to distinguish subzones in full successive sections. Pit and pore sizes of different genera are inversely correlated. Peaks of pit diameters from different locations are indicative of certain levels and therefore applicable to biostratigraphic correlations.
\end{abstract}

\section{INTRODUCTION}

The Senonian ostracods from the lower part of the Mount Scopus Group (Flexer, 1968) in Israel and the biozonation of the Senonian strata are described by Honigstein (1984). The following ostracod assemblage zones, based on the first occurrence of diagnostic species, were established in the Late Coniacian to Campanian sequence. The Phyrocythere lata (S-1) Zone in the Late Coniacian (- ?Early Santonian); the Cythereis rosenfeldi rosenfeldi (S-2) and the Limburgina miarensis (S-3) Zones in the Santonian; the Leguminocythereis dorsocostatus (S-4) and the Brachycythere beershevaensis (S-5) Zones mainly in the Lower Campanian.

Ornamentation is one of the most important taxonomic features in ostracod valves. Within the species, the ornamentation is, in general, remarkably constant (Liebau, 1969). Strongly ornamented forms occur exclusively in marine species, especially among those living in littoral and shallow neritic environments (van Morkhoven, 1962). Reticulation patterns are used by various authors for classification of the Trachyleberididae (e.g. Pokorný, 1969; Liebau, 1969; Damotte, 1976). The details of the sculpture of the left/right valves of one carapace are normally intraspecifically constant (Liebau, 1975). Benson $(1974,1975)$ compares the reticulation of ostracods with engineering structures. The rigid system of ornamentation must be strong enough to preserve the original shape from externally induced mechanical stresses (pressure, turbulation, etc. ..). The decrease in ornamentation, or smoothing factor, may be controlled by the temperature of the biotype (Carbonnel, 1972; Ishizaki, 1975). Hartmann \& Kühl (1978) observed in both smooth and reticulated species a decrease in fine sculpture with a higher level of calcification. The calcium content (or density of calcite grains) of the valves may depend on both the activity of outer epidermal cells and the calcium content in the water (Okada, 1981). Low calcified valves are more strongly ornamented and in high calcified carapaces the structures are weaker (Kühl,
1980). He suggested that the calcification is dependent on the different sediments where the ostracods live, and the seasonal ostracod populations. Shapes of pits and meshes are almost determined by patterns of the epicuticle before ecdysis, namely before calcification, and they are probably independent of calcium content in the water (Okada, 1981). Göttner (1980) presented a positive correlation between the pit size and the salinity of brackish water ostracods.

The soft ostracod body is encased in a bivalved, calcareous shell, which if completely closed would severely limit the ability to sense the external environment. However, ostracods possess pore systems which are open to the exterior. These pores mostly have tactile receptors (setae or hairs) extending from the pores. In Trachyleberididae and Hemicytheridae, the two pore types (simple and sieve-type pores) coexist in valves of the same ostracod (Sandberg \& Plusquellec, 1969). The simple pores are narrow, relatively uniform throughout the shell and have distal setae. Müller (1894) and Hartmann (1966) discussed in some Cytheracea the size variation in normal pores: narrow canals with long, thick hairs acting as touch receptors and wide canals with finer setae for more delicate sensory functions. Other functions of these pores are secretion of the glands (Omatsola, 1970; Puri, 1974) and chemo- or thermotropic operations (Omatsola, 1970). Jørgenson (1970) reported the size of the pore diameter of Trachyleberididae as being approximately 10 microns. The sievetype pore may function as a photoreceptor and has a surrounding sieve plate and as well as a mostly central opening for a seta. As in normal pores, the function of the hair is that of a touch receptor. Müller (1894) assumed that these pores may serve as eyes in ostracods without eye-spots, however, the bristles are not sensitive to light. Liebau (1978) suggested that the pores may also serve as a hearing device. The setae in the pores probably sense vibrations in the water, as do the ciliated cells in the ears of mammals. Some authors used pore types and 
bristles for taxonomic classification (Puri \& Dickau, 1969; Sandberg \& Plusquellec, 1969; Puri, 1974; Keyser, 1980). Studies by Rosenfeld \& Vesper (1977) and Rosenfeld (1977) show that the form of the sievetype pores is an indication of palaeosalinity. In Recent ostracods, the differentiation between the two main types of pores (normal and sieve-type) is easy. Only in very few Senonian specimens from Israel are the fine sieve-type pores preserved, more often they are filled with sediment and the presence or absence of sieve plates cannot be determined.

Reticulation and tuberculation are related to the pore system; these features are genetically fixed and related to sense-organ systems (Liebau, 1969). The pattern of pores on the carapace appears consistent within the species (Puri \& Dickau, 1969). Even ostracods of the same genus have similar uniform pore patterns, whereas the reticulation is a specific feature (Liebau, 1969; Okada, 1982). The evolution of the pores and ornament within a species are correlated (Liebau, 1978) and the network, to which the pore arrangements are related, is composed of meshes which remain in the same positions.

In the present study, an attempt is made for the first time, to measure and compare the size of ornamentation (pits) with the diameter of pores in certain groups of Senonian ostracods and to use these data for stratigraphic purposes.

\section{MATERIAL AND METHODS}

Material for the measurements of pore and pit sizes was selected from about 30 sections (wells and exposures; Fig. 1) from different parts of the country. All the studied material is stored in the collections of the Geological Survey of Israel, Jerusalem, under the Ostracode Laboratory Nos. T-. The ultrasonic cleaning of valves was only used in very soiled specimens, where the details of the structures could not be observed. The cleaning procedure normally leads to a weakening and flattening of the ornamentation in pitted specimens. The structures were photographed at different magnifications using the scanning electron microscope (S.E.M.) of the Hebrew University, Jerusalem, and the Geological Survey of Israel, and the diameters were measured on the photographs. At a later stage of the study, measurements were taken directly from the S.E.M. screen.

From each sample, an average of four specimens were selected for examination. The pores of two different groups of Trachyleberididae and Hemicytherididae (reticulated and pustulated type) were measured on different parts of the valve (minimum about 10 pores/ specimen) and the results averaged. Ostracods of the pustulated type belong to the species Phyrocythere lata Honigstein, 1984 and Veenia fawwarensis Honigstein, 1984 (both subspecies), whereas the reticulated group is formed by Cythereis cretaria Bold, 1964, and its subspecies, Anticythereis judaensis Honigstein, 1984 and
Ventrocythereis sinaiensis Honigstein, 1984. From the same samples, however, a comparable amount of specimens of Brachcythere is taken ( $B$. angulata Grekoff, 1951, B. cf. B. ekpo Reyment, 1960, and B. beershevaensis Honigstein, 1984). Here, the pit diameters were measured from the anterior and central area of the valve (for oblong pits, measurements are approximate). In general, pores in Brachycythere were not possible to observe, as they are mostly very narrow and filled with marl. Pores and pits were only clearly distinguished in a few specimens (see Pl. 1, figs. 4, 5). Therefore, only pits of Brachycythere were used in this study. For a statistical check, nearly 200 specimens from one sample were measured (Ein el Fawwar, Location No. 24, Ostracode Lab. No. T-7515; Figs. 1, 2). The results of pore and pit measurements are summarised in Figs. 3-10. Valves of Brachycythere with different pit diameters are illustrated on Plate 1.

\section{RESULTS}

Preliminary examination of pore and pit sizes show that the same average values were obtained for female or male specimens as for left or right valves of adult ostracods from the same samples (cf. Liebau, 1975). This applies to all ostracod groups observed (reticulated/ pustulated types + Brachycythere). Pore size is nearly uniform throughout the entire carapace. Within the same specimens there were only small variations in the diameter data observed.

For example, in specimens of Cythereis cretaria and Anticythereis judaensis from Ayyalon-3 (Fig. 1), Ostracode Lab. No. T-7559, the single measurements of pores range between 4.7 and $6.0 \mu \mathrm{m}$, the average diameter for each specimen (8-10 pores/specimen) being between 5.2 and $5.6 \mu \mathrm{m}$; the average diameter for all specimens in the sample is, therefore, about $5.4 \mu \mathrm{m}$. A total of 200 pits in the central areas of 25 specimens of Brachycythere angulata from Nahal Massor 3, Location No. 55, Ostracode Lab. No. 7305 (Figs. 1, 10) were measured, the results of which are shown in the following table:

\begin{tabular}{cc}
\hline Number of measurements & Pit diameter (in microns) \\
\hline 3 & 5.3 \\
19 & 6.0 \\
84 & 6.6 \\
73 & 7.3 \\
18 & 8.0 \\
3 & 8.6 \\
\hline
\end{tabular}

The pore and pit diameter averages are consistent for each sample and are therefore reliable for data processing. The total range in pore size of all studied specimens from different locations and stratigraphic levels is $3-7 \mu \mathrm{m}$ and in pit diameter $2-11 \mu \mathrm{m}$. These ranges are greater than the possible error of measurements under the S.E.M., which is about $10 \%$. 
A control experiment with 191 specimens of Brachycythere shows a normal distribution of the pit diameter (Fig. 2), the average of four specimens/sample (minimum 10 pits/specimen measured) is proved to be sufficiently valid. The standard deviation of average measurements of the pits is given in Fig. 5.

The pits of Brachycythere are much larger in the central than in the anterior zone (Pl. 1, fig. 6). The results of the ornamentation measurements on different areas on the carapace yielded congruent curves. The maxima and minima, respectively, occur in the same sample of the pit size measured both in the central and anterior area (Fig. 3). Thus, pit sizes of Brachycythere in the peripheral zones of the valves were neglected. The diameter of the pores is almost constant in ostracods, both in reticulated and pustulated forms from the same stratigraphic level (Fig. 4). Therefore, both types were used together for this study. Diagrams of pore versus pit diameter show a mirror-like picture, but with incongruent amplitudes. For the same stratigraphic level, every

Fig. 1. Location Map (modified after Honigstein, 1984)

\begin{tabular}{|c|c|c|c|}
\hline \multicolumn{3}{|c|}{ List of Localities } & \multirow{2}{*}{$\begin{array}{l}\text { Coordinates } \\
\text { (Israel grid) }\end{array}$} \\
\hline Region & No. & Location & \\
\hline \multirow[t]{9}{*}{ Galilee: } & 20 & Damun-7* & $1650 / 2505$ \\
\hline & 28 & Galed-3* & $1556 / 2187$ \\
\hline & 45 & Ketar Hittim-B* & $1951 / 2471$ \\
\hline & 48 & Megiddo- I * & $1678 / 2209$ \\
\hline & 49 & Menashe* & $1486 / 2080$ \\
\hline & 50 & Miar* & $1708 / 2541$ \\
\hline & 70 & Rewaya- $3^{*}$ & $1918 / 2041$ \\
\hline & 74 & Shefar am-1: & $1619 / 2467$ \\
\hline & 81 & Wadi-a-Namer & $2008 / 1893$ \\
\hline \multirow[t]{7}{*}{ Central: } & 4 & Ayyalon- $3^{*}$ & $1454 / 1421$ \\
\hline & 24 & Ein el Fawwar & $1830 / 1386$ \\
\hline & 25 & Ein el Qilt & $1856 / 1381$ \\
\hline & 40) & Har Tuv-2* & $1501 / 1292$ \\
\hline & +1 & Har Tuv-3* & $1509 / 1298$ \\
\hline & 71 & Rogelit-2* & $1528: 1190$ \\
\hline & 72 & Shaar HaGay & $1525 / 1355$ \\
\hline \multirow[t]{9}{*}{ Negev: } & 6 & Bat $-1 A^{*}$ & $1532 / 0738$ \\
\hline & 9 & Beersheva-SH9* & $1319 / 0726$ \\
\hline & 13 & Bir-es-Saqati-1** & $1413 / 0799$ \\
\hline & 18 & Dabeshet-1* & $1687 / 0811$ \\
\hline & 32 & Gurim-SH4* & $1740 / 0664$ \\
\hline & 54 & Nahal Massor 2 & $1608 / 0164$ \\
\hline & 55 & Nahal Massor 3 & $1611 / 0167$ \\
\hline & 82 & Yorqeam-1* & $1600 / 0325$ \\
\hline & 86 & Zohar-5* & $1700 / 0669$ \\
\hline
\end{tabular}

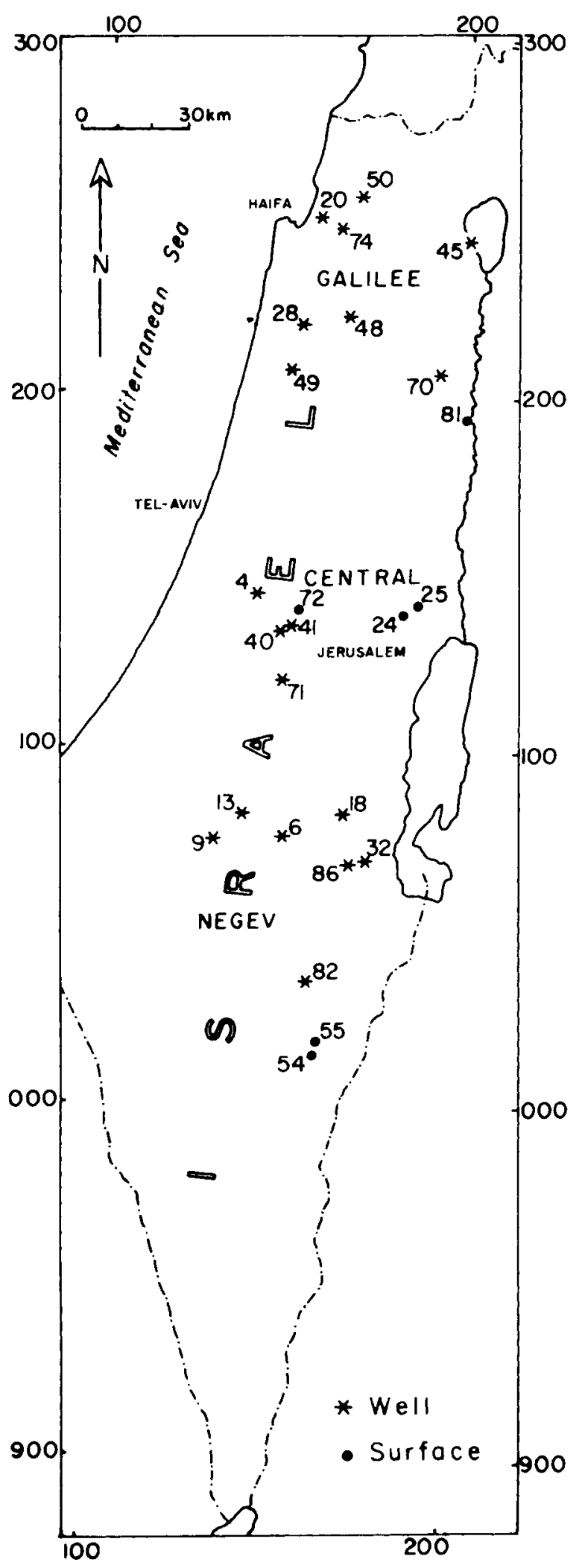


decrease in the pit size is equivalent to an increase in the pore diameter and vice versa (Figs. 4, 8). No evolutional trend for the development of pore and pit sizes is noticed.

Data from different locations (Figs. 3-6; 9-10) demonstrate that the size of ornamentation is dependent on certain stratigraphic horizons. The ostracod assemblage zones S-1 to S-5 (Honigstein, 1984) were superimposed on these results and only small deviations are shown for different locations (e.g. top of the S-3 Zone in Fig. 6: Bir-es-Saqati-1 and relatively large pit sizes in the

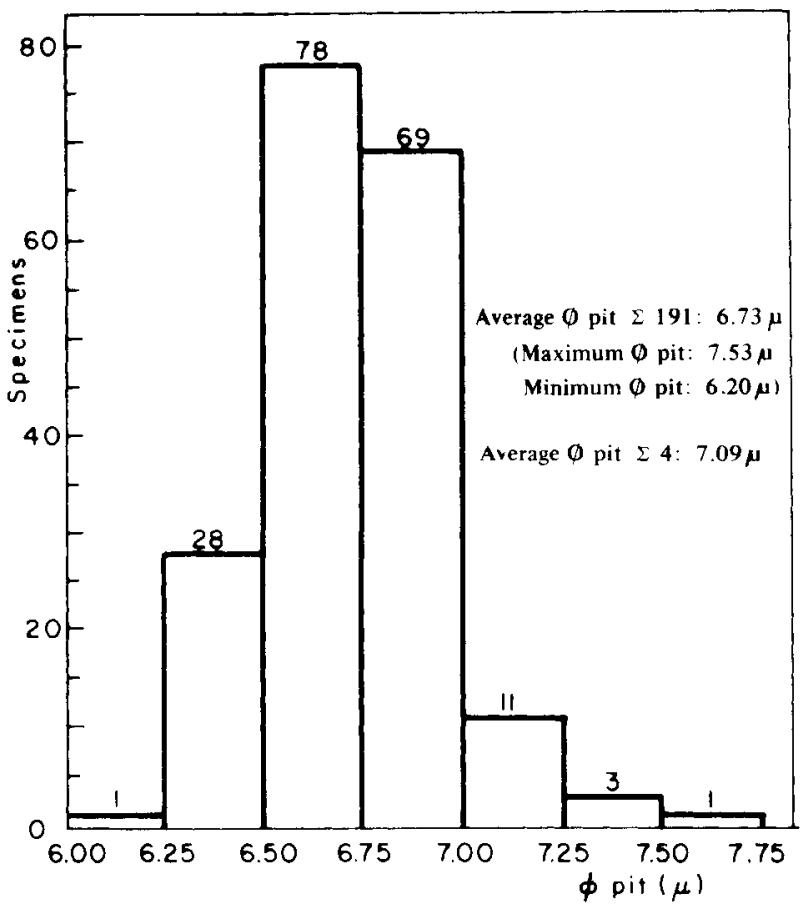

Fig. 2. Normal distribution of diameter pit of Brachycythere for Location No. 24: Ein el Fawwar, Ostracode Lab. No. T-7515.
S-2 Zone of Nahal Massor 3, Fig. 10). Therefore, average curves were drawn for the studied material from each region and all assemblage zones (Fig. 7). Only insignificant variations in the amplitudes were observed.

This gave rise to the construction of a comprehensive diagram for all sections measured (Fig. 8). Specimens of Brachycythere show low pit diameter peaks in the assemblage Zones $\mathrm{S}-2$ and $\mathrm{S}-4$, medium values in the S-3 Zone and high maxima in the S-5 Zone (not only for the large species $B$. beershevaensis). The different ostracod assemblages of the S-2 and S-4 Zones allow an easy distinction between the peaks of similar amplitude. The minima, except in the S-5 Zone, are nearly of the same value. Every assemblage zone (except the S-1 Zone, where only few ostracods were measured) can be divided into two or three parts according to the variation in pit diameter in full successive sections. The pore diameters in trachyleberidid (and hemicytheridid) ostracods gave, for nearly all samples, mirror-like results to those of the pits of Brachycythere, but the amplitudes are smaller and single peaks for certain stratigraphic levels cannot be identified. Also, the ornaments of the pitted species are easier to recognise (larger size and better preservation). Therefore, pores should only be measured for completion of data intervals, where Brachycythere is lacking.

\section{DISCUSSION AND CONCLUSIONS}

The variations in the pore diameter seen in some genera of Trachyleberididae and Hemicytherididae are related to the size of ornamentation of the examined species of Brachycythere. An evolutionary trend is excluded and so the palaeoecology may have influenced these size changes. Some attempts were made in this study to combine the ultrastructural data with palaeoenvironmental factors.

Stable isotope studies (oxygen and carbon isotopes) were abandoned after the rather disappointing results with Recent ostracods, reported by Durazzi (1977).

\section{Explanation of Plate 1}

Different pit diameters in Brachycythere

Scale bar $=20$ microns; figs. 1-5, same magnification

Fig. 1. Brachycythere angulata Grekoff, Central area. Average pit diameter $=4,1 \mu \mathrm{m}$; Ein el Fawwar.

Fig. 2. Brachycythere angulata Grekoff, Central area. Average pit diameter $=6,5 \mu \mathrm{m}$; Shaar HaGay.

Fig. 3. Brachycythere angulata Grekoff, Central area. Average pit diameter $=7,5 \mu \mathrm{m}$; Shaar HaGay.

Fig. 4. Brachycythere angulata Grekoff, Central area. Average pit diameter $=9,5 \mu \mathrm{m}$; Har Tuv-3.

Fig. 5. Brachycythere cf. B. ekpo Reyment, Central area. Average pit diameter $=12,4 \mu \mathrm{m}$; Ein el Qilt.

Fig. 6. Brachycythere angulata Grekoff, Anterior area. Average pit diameter $=2,8 \mu \mathrm{m}$; Ein el Fawwar. 

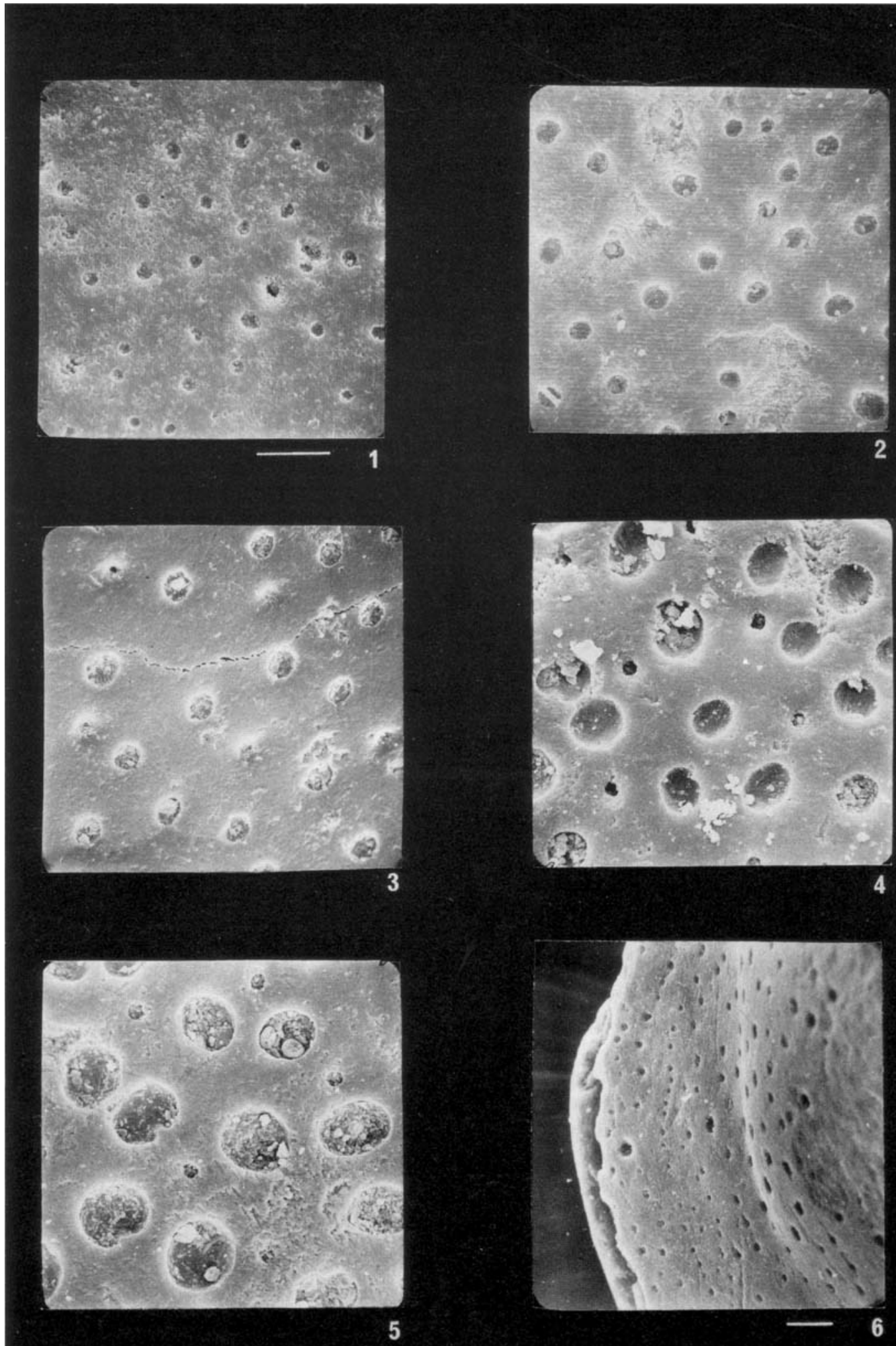


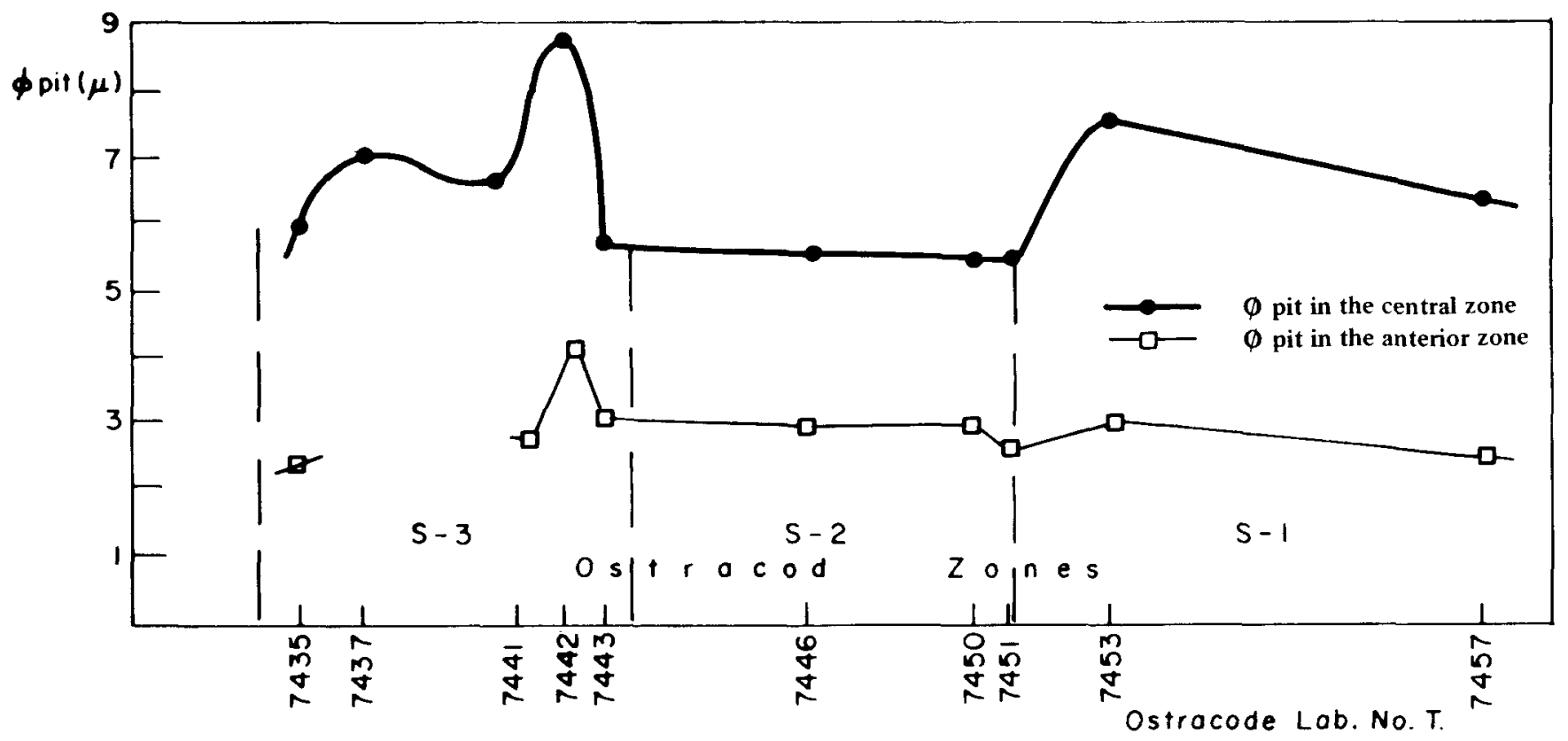

Fig. 3. Diagram of diameter pit of Brachycythere for Location No. 72: Shaar HaGay.

Bandel \& Hoefs (1975) mentioned, by studying gastropods, that metabolic processes during carbonate precipitation seem to affect the isotopic composition of the shells. This makes the determination of water (palaeo-) temperature and (palaeo-) salinity impossible. Biological mechanisms may, therefore, affect the calcification of ostracod shells. The structure of an ostracod carapace and its building process is very complex (Rosenfeld, 1979; Okada, 1982). In addition, in the studied material, single valves, necessary for isotopic analyses, are relatively rare.

By the usual washing technique for foraminifera and ostracods (sieve mesh size $76 \mu \mathrm{m}$ ), the fraction, which contains the highest number of specimens, is lost (fraction finer than $64 \mu \mathrm{m})$. Thus, the determined plankton benthos ratio, a factor indicating depth of deposition, is not accurate (Black, 1980; C. Benjamini, Beersheva University, pers. comm.). Therefore, the relationship between this ratio and the ultrastructural data of ostracods have not been examined in the present study.

Starinsky \& Flexer (1969) and Flexer \& Starinsky (1970) mentioned phosphate contents in Senonian rocks as a factor related to plankton/benthos ratio and employed this new factor as a palaeobathymetric indicator. An increase in the $\mathrm{Mg} / \mathrm{Ca}$ ratio in the environment causes greater ornamentation of ostracod tests and a decrease in this factor results in a smoothening of ornaments (Peypouquet et al., 1980). Phosphate, $\mathrm{Mg}$ and $\mathrm{Ca}$ contents were analysed in about thirty samples of two sections (Rewaya-3: wel!, Galilee and Nahal Massor 3: surface, Negev) by the Geochemical Division of the G.S.I., Jerusalem. Their results were superimposed on the data of pit diameter measurements of Brachycythere from the same samples. The diagram for Rewaya-3 (Fig. 9) shows rather conformable trends of the curves of pit sizes and the $\mathrm{Mg} / \mathrm{Ca}$ ratio; phosphate contents gave incomparable results. However, the data for Nahal Massor 3 (Fig. 10), where more samples were taken in a narrower stratigraphic interval, did not agree with the observations of the Rewaya- 3 diagram. It seems that changes in the ornamentation of ostracods cannot be correlated with phosphate content (depth) neither with the amount of magnesium in the rocks (dolomitisation).

Preliminary studies were carried out by the author on Recent ostracods from the Gulf of Naples. In the depth interval of $30-200 \mathrm{~m}$, a steady increase in the pit size of Bosquetina dentata (Müller, 1894) with water depth could be observed. This species is similar to the Senonian Brachycythere in both ornamentation and taxonomic position. The similarity would therefore suggest an increase in pit diameter in Brachycythere with water depth. The pore size changes, which show inverse correlation with the pit size in the Senonian species, do not seem to show any significant variation in the Recent 


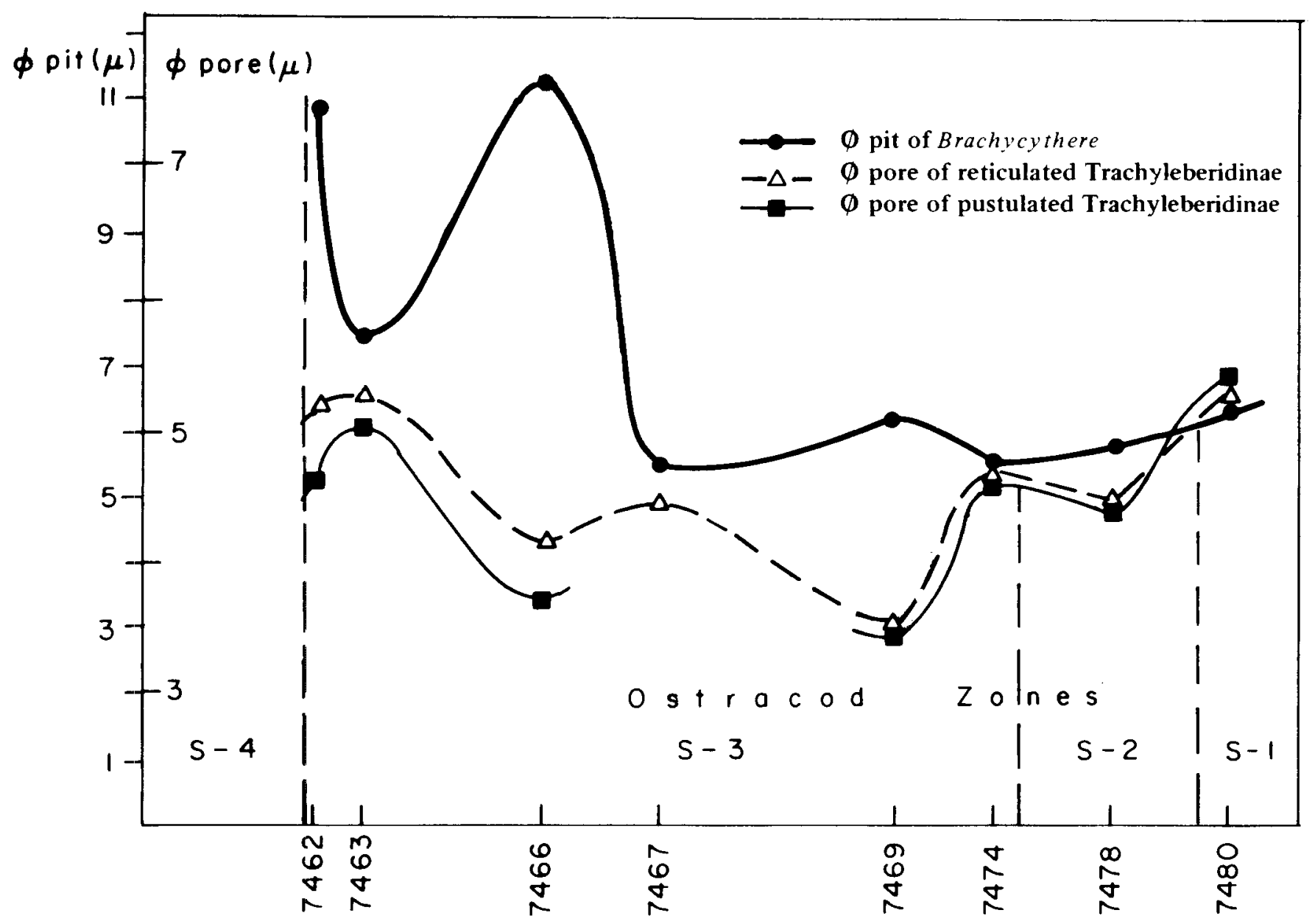

Fig. 4. Diagram for Location No. 25: Ein el Qilt.

trachyleberidid ostracods examined here. The Recent genera, Pterygocythereis, Carinocythereis and Acanthocythereis, were found to yield nearly the same pore size in all depth intervals, but it is possible that an insufficient number of specimens were studied for definitive conclusions to be drawn.

The results of the ultrastructural observations of the pore size of Trachyleberididae and Hemicytheridae and the pit diameter in Brachycythere were proved to be valuable for biostratigraphic purposes. The size variations of the pores are inversely correlated with those of the pits. The size ranges are consistent in certain stratigraphic levels from all parts of Israel. The method might be useful in order to differentiate between subzones and improve the boundary lineation of the asse mblage zones in full successive sections. For the application of the size variations as a stratigraphic tool, identification to specific level in ostracods is unnecessary. Only a few specimens of pitted forms are required. It is noteworthy that this method can be used even when age diagnostic ostracods are absent. Further, more detailed work on Recent ostracods may indicate the ecological factor(s) responsible for the combined changes in pit and pore size.

\section{ACKNOWLEDGEMENTS}

I wish to thank Dr. H. J. Oertli, Elf Aquitaine, Pau, Dr. A. Rosenteld, Geological Survey of Israel, Jerusalem, and Dr. Y. Okada, Nippon University, Tokyo, for constructive criticism of this manuscript. I am indebted to Prof. Z. Reiss, Hebrew University, Jerusalem, and Prof. A. Hlexer, Tel-Aviv University, for helpful comments and encouragement of this study. Material of Recent ostracods was gratefully received by Dr. G. Bonaduce, Stazione Zoologica, Naples. Many thanks are due to Mr. M. Dvorachek and Mr. R. Knafo, Geological Survey of 1srael, and the S.E.M. team of the Hebrew University, for their nearly endless efforts at the scanning electron microscope and Mr. A. Peer, Geological Survey of Israel, for the drawings.

Manuscript received February 1985 Manuscript accepted April 1985 


\section{REFERENCES}

Bandel, K. \& Hoefs, J. 1975. Die Isotopenzusammensetzung von Molluskenschalen am Beispiel der Gastropoden. $N$. $J b$. Geol. Palaeont., Mh., 1975 (1), 1-11.

Benson, R. H. 1974. The role of ornamentation in the design and function of the ostracode carapace. Geoscience and Man, 6, 47-57, 1 pl.

Benson, R. H. 1975. Morphologic stability in Ostracoda. Bull. Amer. Paleont., 65, 13-46.

Bold, van den, W. A. 1964. Ostracoden aus der Oberkreide von Abu Rawash, Aegypten. Palaeontographica, Abt. A, 123 (4-6), 111-136, pls. 13-15.

Black, M. 1980. On chalk, Globigerina ooze and aragonite mud. In Jeans, C. V. \& Rawson, P. F. (Eds.), Andros Island, chalk and ozeanic oozes. Unpublished work of Maurice Black. Yorkshire Geol. Soc., Occ. Publ., 5, 54-85, pls. 1-6.

Carbonnel, G. 1975. Le facteur lisse chez certains Ostracodes tertiaires: Un index de paleotemperature. Bull. Amer. Paleont., 65, 277-301, pls. 1-2.

Damotte, R. 1976. L'ornamentation reticulée chez les Ostracodes. Description morphologique, origine et importance. Trav. Lab. Micropal., 6, 155-171, pls. 1-3.

Durazzi, J. T. 1977. Stable isotopes in the Ostracod shell: a preliminary study. Geochim. Cosmochim. Acta, 41 (8), $1168-1170$.
Flexer, A. 1968. Stratigraphy and facies development of Mount Scopus Group (Senonian-Paleocene) in Israel and adjacent countries. Isr. J. Earth Sci., 17, 85-114.

Flexer, A.\& Starinsky, A. 1970. Correlation between phosphate content and the foraminiferal plankton/benthos ratio in chalks (Late Cretaceous, Northern Israel): Paleoenvironmental significance? Sedimentology, 14, 245-258.

Göttner, J. -J. 1980. Der Einfluss unterschiedlicher Umweltfaktoren auf Grössenwachstum und Schalenbau bei Ostracoden. Berliner Geowiss. Abh., (A), 27, 71-117, pls. 1-5.

Grekoff, N. 1951. Quelques Ostracodes nauveaux du Sénonien supérieur du Cameroun. Rev. Inst. Franç. Pétrole, 6, 53-59, pls. 1-2.

Hartmann, G. 1966. Ostracoda. In Bronn, H. G., Klassen und Ordnungen des Tierreichs. 5. Klasse, 1. Ordn., 2. Buch, 4. Teil, 1. Lief, 1-216, Geest \& Portig, Leipzig.

Hartmann, G. \& Kühl, C. 1978. Zur Variabilität der Oberflächenelemente der Schalen lebender Ostracoden-Populationen. Mitt. Hamb. Zool. Mus. Inst., 75, 221-223, pls. 15-19.

Honigstein, A. 1984. Senonian Ostracodes from Israel. $/ s r$. Geol. Surv., Bull., 78, 1-48, pls. 1-15.

Ishizaki, K. 1975. Morphological variation in Leguminocythereis? hodgii (Brady), Ostracoda (Crustacea), from Japan. Bull. Amer. Paleont., 65, 245-261.

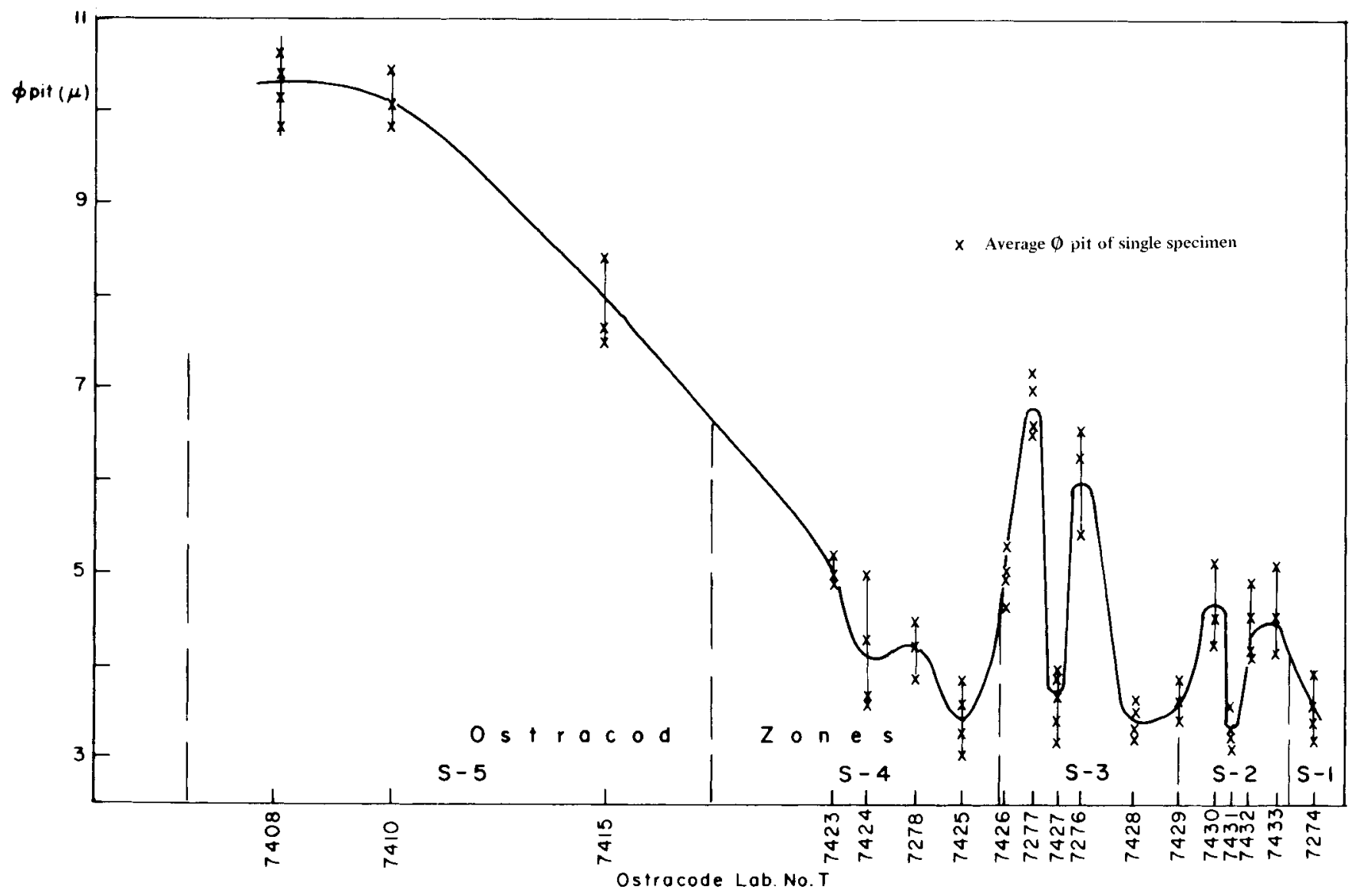

Fig. 5. Diagram of diameter pit of Brachycythere for Location No. 48: Megiddo-1*. 
Jørgensen, N. O. 1970. Ultrastructure of some Ostracods. Bull. Geol Soc. Denmark, 20, 79-92, pls. 1-7.

Keyser, D. 1980. Auftreten und Konstanz von Poren und Borsten auf der Schale von Podocopa (Ostracoda, Crustacea). Verh. Naturwiss. Ver. Hamburg, (NF), 23, 175-193, pls. 1-3.

Kühl, C. 1980. Die Variabilität von Leptocythere psammophila Guillaume, 1976: Schalenabmessungen und Schalenstrukturen (Crustacea: Ostracoda: Cytheridae).Verh. Naturwiss. Ver. Hamburg, (NF), 23, 275-301, pls. 1-7.

Liebau. A. 1969. Homologisierende Korrelationen von Trachyleberididen-Ornamenten (Ostracoda, Cytheracea). N. Jb. Geol. Palaeont., Mh., 1969 (7), 390-402.

Liebau, A. 1975. The left-right variation of the Ostracode ornament. Bull. Amer. Paleont., 65, 77-86, 1 pl.

Liebau, A. 1978. Die Evolution der Trachyleberididen-Poren - Differentiation eines Sinnesorgansystems. N. Jb. Geol. Palaeont., Abh., 157 (1-2), 128-133.

Morkhoven, Van, F. P. C. M. 1962.Post-Paleozoic Ostracoda. Part 1: General. 1-204. Elsevier, Amsterdam.

Müller, G. W. 1894.Die Ostracoden des Golfes von Neapel und der angrenzenden Meeres-Abschnitte. Pubbl. Staz. Zool. Napoli, Monograph 21: 1-404, pls. 1-40. Friedländer, Berlin.
Okada, Y. 1981. Development of cell arrangement in ostracod carapaces. Paleobiology, 7 (2), 276-280.

Okada, Y. 1982. Ultrastructure and pattern of the carapace of Bicornucythere bisanensis (Ostracoda, Crustacea). In Hanai, T. (Ed.), Studies on Japanese Ostracoda, 229-255, pls. 16-30. Univ. of Tokyo Press.

Omatsola, M. E. 1970 . On structure and morphologic variation of normal pore system in Recent Cytherid Ostracoda (Crustacea). Acta Zool., 51, 115-124, pis. 1-3.

Peypouquet, J. P., Ducasse, D., Gayet, J. \& Pratviel, L. 1981. "Agradation et dégradation" des tests d'Ostracodes. Intérêt pour la connaissance de l'évolution paléohydrologique des domaines margino-littoraux carbonatés. Symposion Carbonates, Bordeaux, 1980, 357-369, Bordeaux.

Pokorný, V. 1969. The genus Radimella Pokorný, 1969 (Ostracoda, Crustacea) in the Galapagos Islands. Acta Univ. Carolinae, Geologica, 1968 (4), 293-334.

Puri, H. S. 1974. Normal pores and the phylogeny of Ostracoda. Geoscience and Man, 6, 137-151, pls. 1-13.

Puri, H. S. \& Dickau, B. E. 1969. Use of normal pores in taxonomy of Ostracoda. Trans. Gulf Coast Assn. Geol. Soc., 19. 353-367, pls. 1-6.

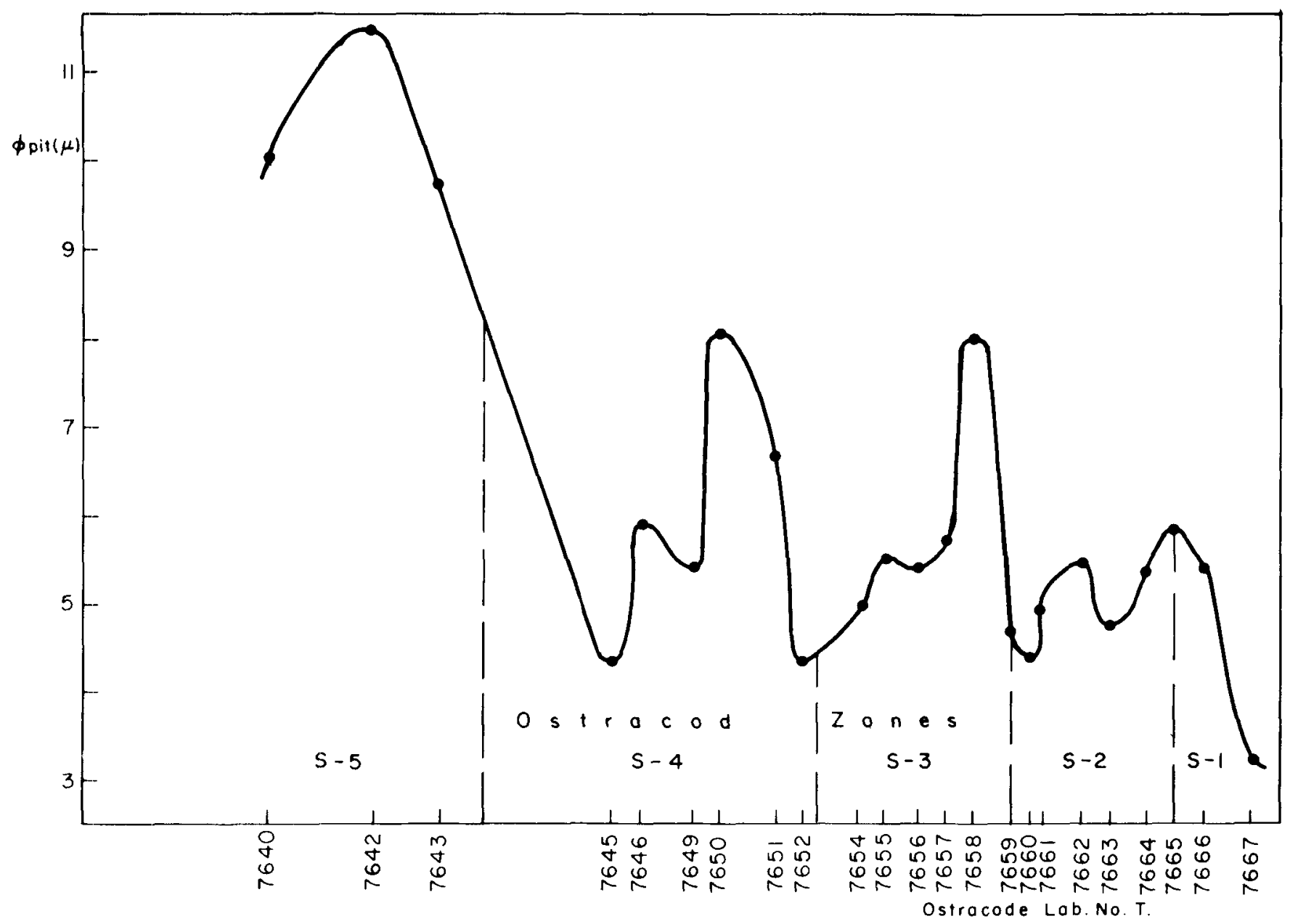

Fig. 6. Diagram of diameter pit of Brachycythere for Location No. 13: Bir-es-Saqati-1*. 
Reyment, R. 1960. Studies on Nigerian Upper Cretaceous and Lower Tertiary Ostracodes. Part 1: Senonian and Maestrichtian Ostracoda. Acta Univ. Stockh. Contrib. Geol., 7, 1-238, pls. 1-28.

Rosenfeld, A. 1977. The sieve pores of Cyprideis torosa (Jones, 1850) from the Messian Mavqi'im formation in the Coastal Plain and Continental Shelf of Israel as an indicator of paleoenvironment. Isr. J. Earth Sci., 26 (3-4), 89-93, $1 \mathrm{pl}$.

Rosenfeld, A. 1979. Structure and secretion of the carapace in some living Ostracodes. Lethaia, 12, 353-360.

Rosenfeld, A. \& Vesper, B. 1977. The variability of the sievepores in Recent and fossil species of Cyprideis torosa (Jones, 1850) as an indicator for salinity and paleosalinity. Sixth Intern. Ostracod Symposium, Saalfelden, 1976, 55-57, $1 \mathrm{pl}$. W. Junk Publ., The Hague.

Sandberg, P. A. \& Plusquellec, P. L. 1969. Structure and polymorphism of normal pores in Cytheracean Ostracoda (Crustacea). Jour. Paleont., 43 (2), 517-521, 1 pl.

Starinsky, A. \& Flexer, A. 1969. Habitat of phosphate in Senonian and Maastrichtian chalks in Galilee. Isr. J. Earth Sci., 18 (3-4), 171-172.

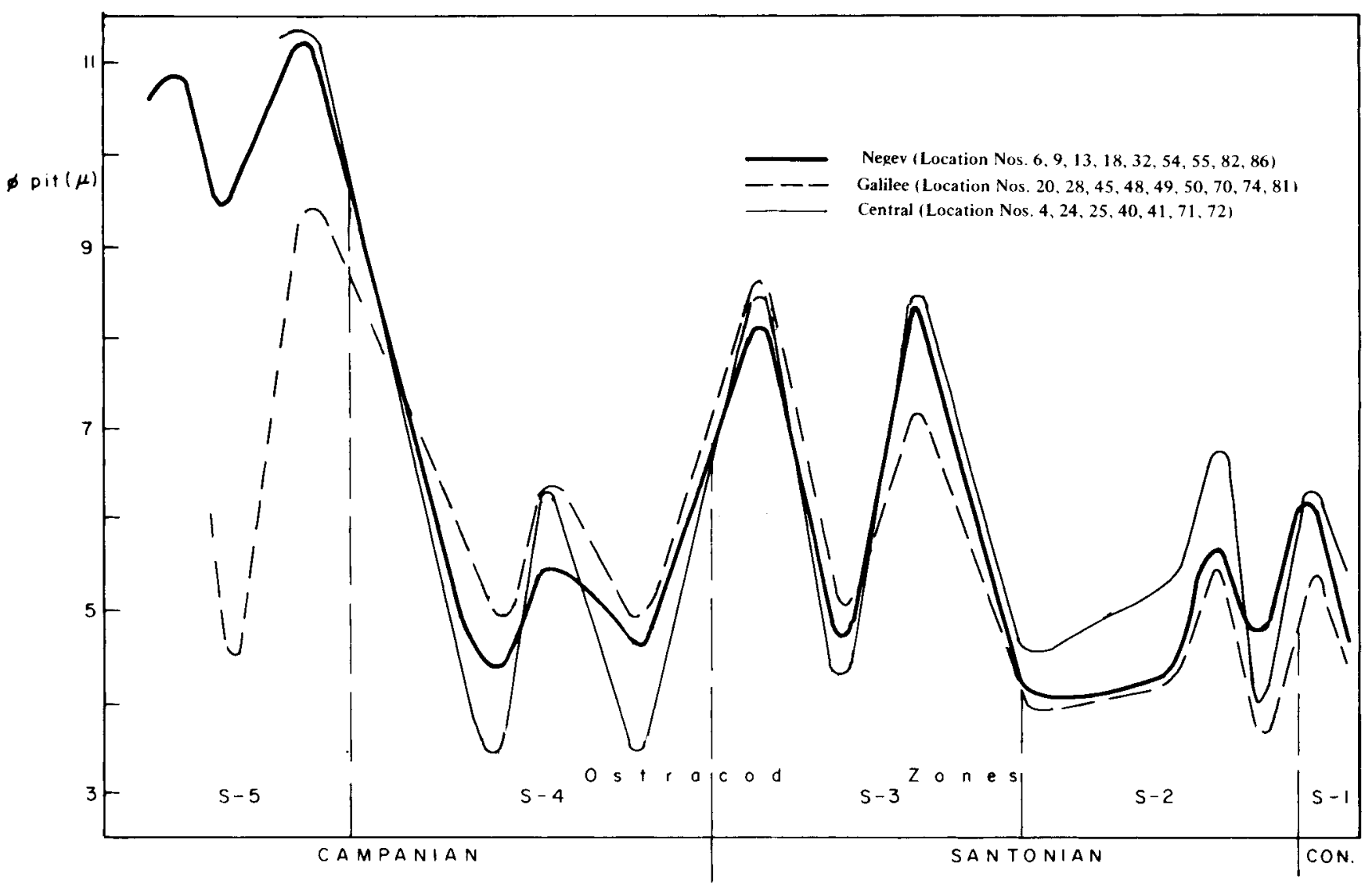

Fig. 7. Average diagram of diameter pit of Brachycythere for the Galilee-, the Negev-and the Central Region. 


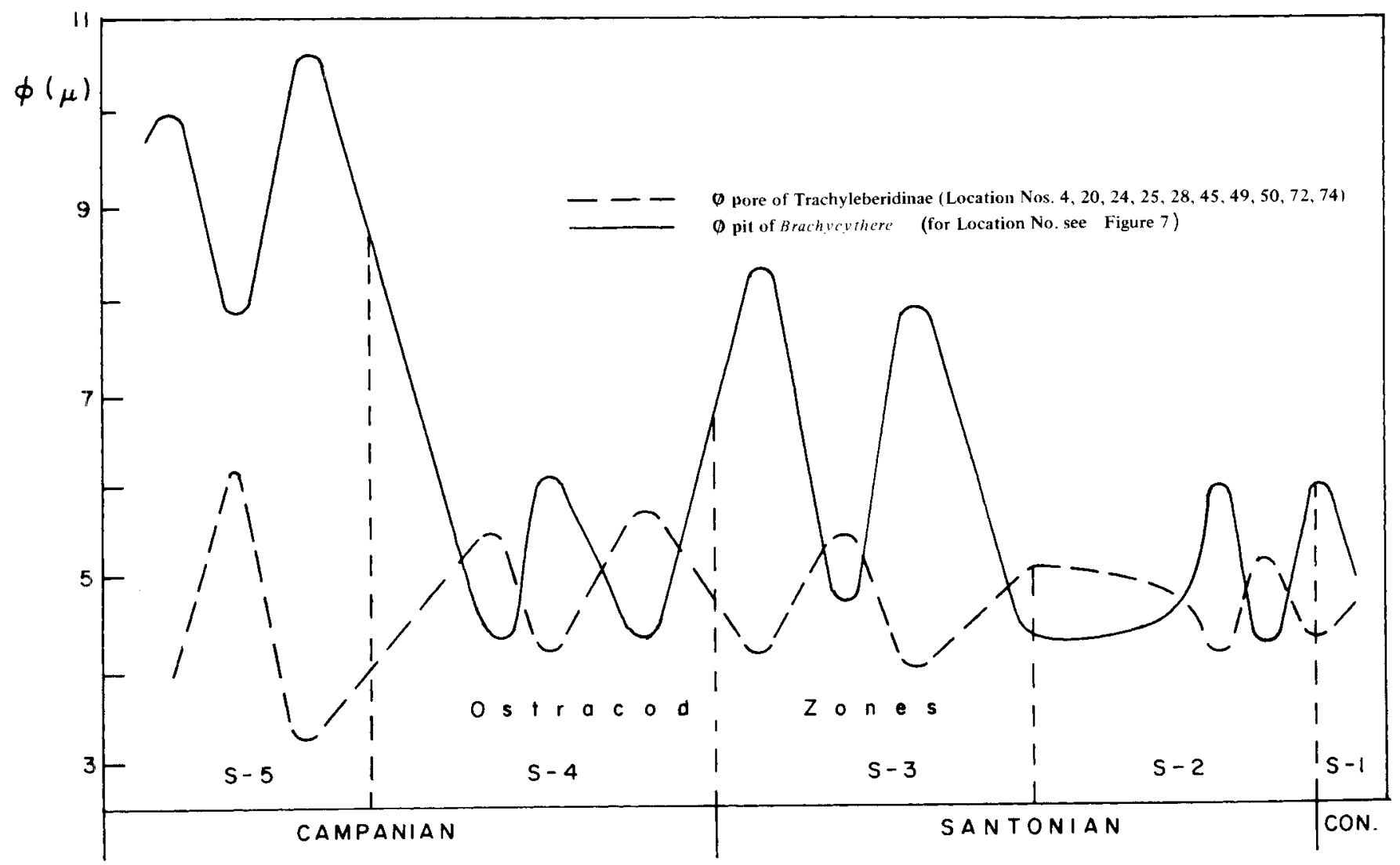

Fig. 8. Average diagram for all sections measured. 


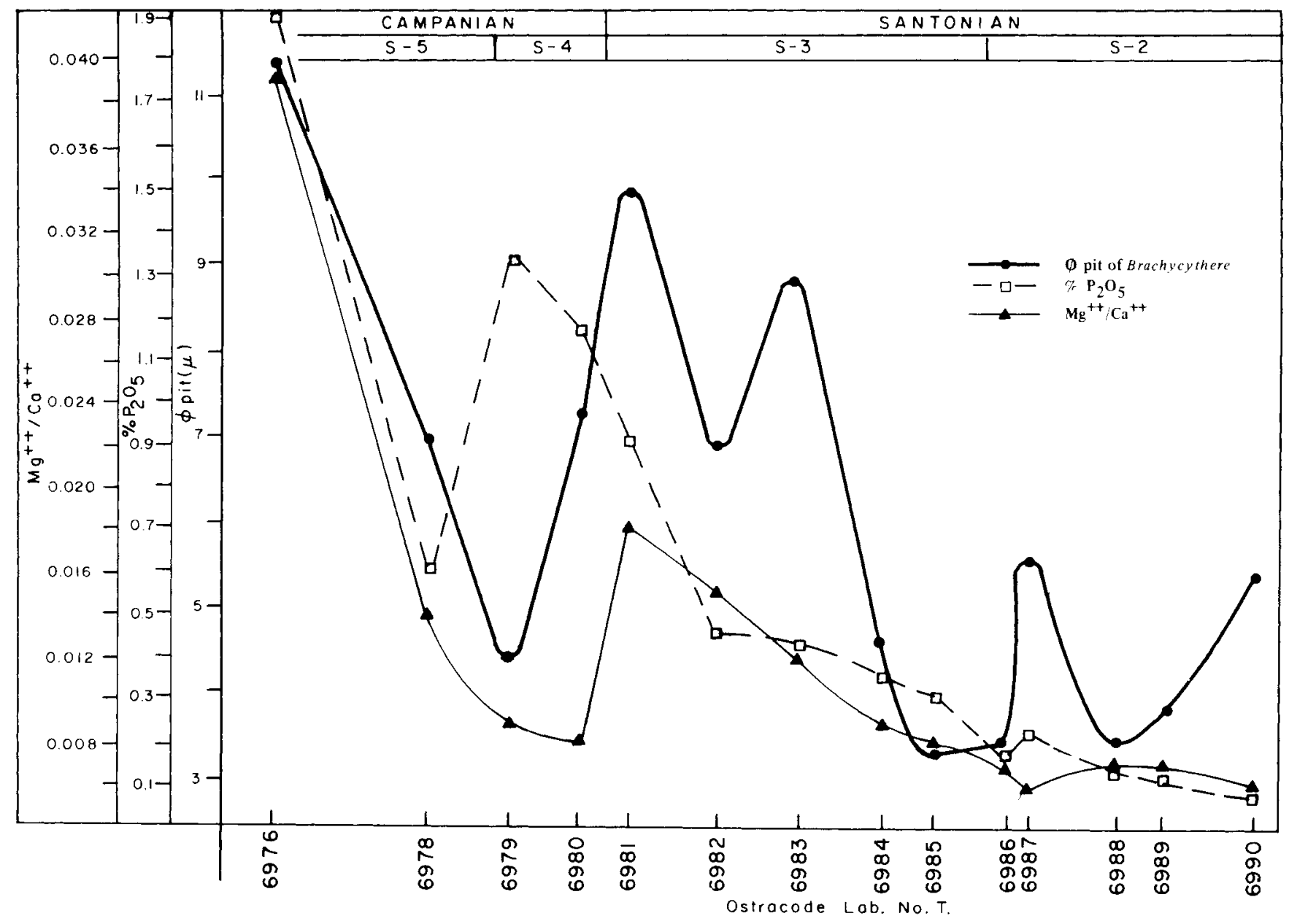

Fig. 9. Diagram for Location No. 70: Rewaya-3*. 


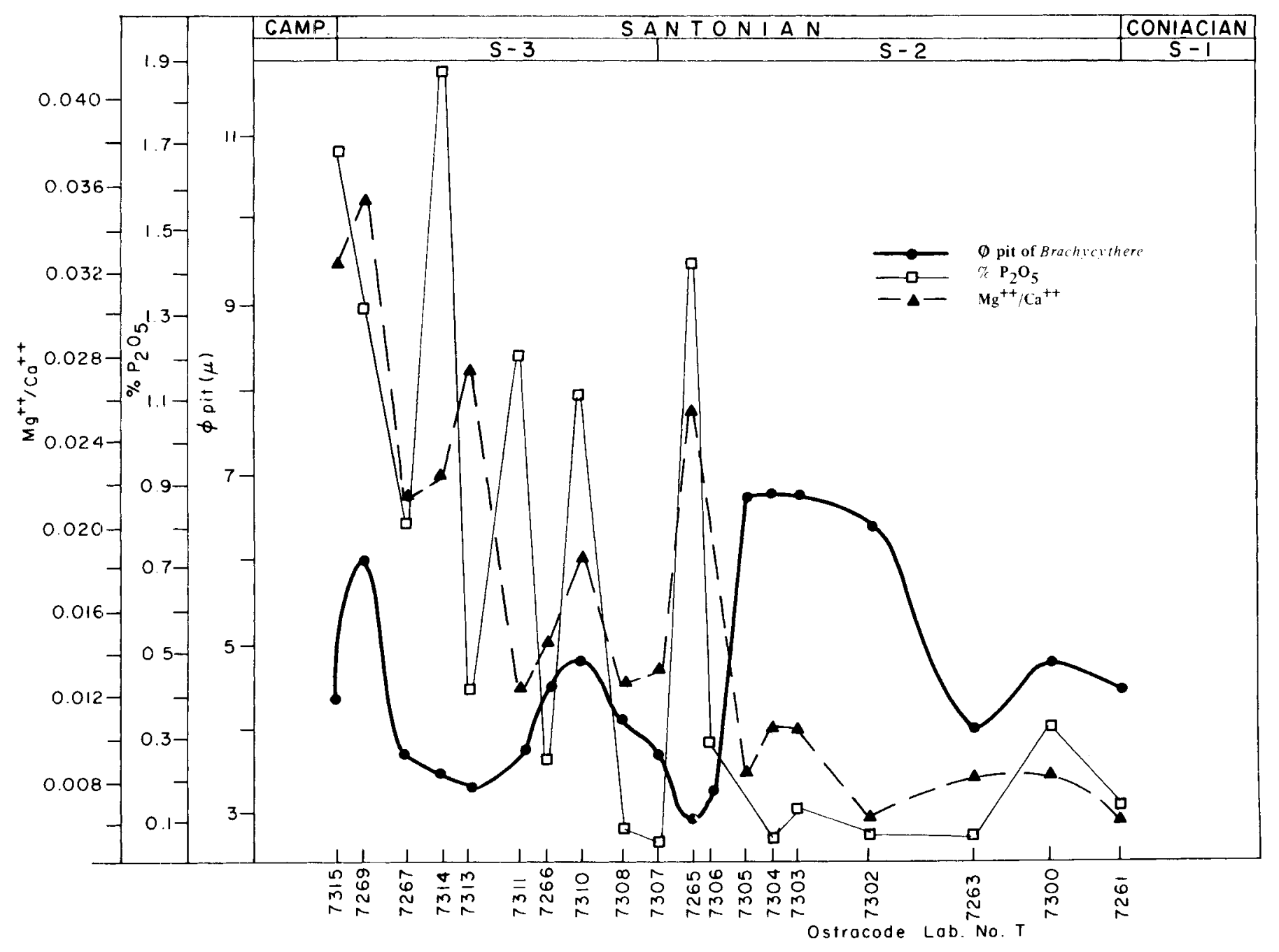

Fig. 10. Diagram for Location No. 55: Nahal Massor 3. 